\title{
Marching towards personalized surgery, fewer complications, higher survival rates
}

\author{
Yasir Gulzar Malik ${ }^{1}$ (D), Dejan Ignjatovic ${ }^{2}$ (D) \\ 1 Department of Digestive Surgery, Akershus University Hospital, University of Oslo, Lorenskog, Norway

The past 15 years have resulted in dramatic changes in the treatment of colon cancer. The most significant development, since the work of Werner Hohenberger (1), lies in the fact that the Norwegian cancer registry demonstrates a steady improvement in 5year survival rates within this same period. What is most astonishing is the fact that the chemotherapy regimen has been stable within the whole period. The conclusion drawn therefore is: it is possible to achieve better long-term survival rates through "just performing better surgery". If correct, such a trend could in turn, lead to the decline of chemotherapy use in the treatment of colon cancer. Never the less, "just better surgery" does require a definition.

When analyzed, the history of surgical education has focused on the surgeon, his apprentice, the surgical procedure and has seldom shown any interest in the individuality of or the variability in the patient. As has been successfully demonstrated through the work of Spasojevic (2) and Naesgaard (3), this individuality and variability can and should lead to the individualization and personalization of surgery.

Allow us to simplify the case. Drawing lines where the surgeon should divide the tissue will not be sufficient for all patients. Modern radiology allows for the preoperative awareness of the anatomy (through segmentation and 3D reconstruction (4)) that will in turn allow the surgeon to approach anatomical structures in a more responsible manner, from outside the lymphatic flow. Thus, the definition of "just better surgery" entails preoperative anatomical awareness than enables us to approach vessel origins (perform the lymphadenectomy) from outside the lymphatic flow (5). Personalized surgery should improve survival rates, reduce complications and the need for chemotherapy in most patients treated for localized colon cancer.

$$
\begin{aligned}
& \text { The author declares no conflict of interest. } \\
& \text { Yazarlar arasında çıkar çatışması yoktur. } \\
& \text { Funding : none / Finansal Destek: yoktur } \\
& \text { doi: https://dx.doi.org/10.33713/egetbd.506686 }
\end{aligned}
$$

\section{References}

1. Hohenberger W, Weber K, Matzel K, Papadopoulos T, Merkel $S$ (2009) Standardized surgery for colonic cancer: complete mesocolic excision and central ligation-technical notes and outcome. Colorectal Dis 11(4):354-364 discussion 64-5

2. Spasojevic M, Stimec BV, Dyrbekk AP, Tepavcevic Z, Edwin B, Bakka A et al (2013) Lymph node distribution in the d3 area of the right mesocolon: implications for an anatomically correct cancer resection. A postmortem study. Dis Colon Rectum 56(12):1381- 1387

3. Nesgaard JM, Stimec BV, Soulie P, Edwin B, Bakka A, Ignjatovic D (2018) Defining minimal clearances for adequate lymphatic re- section relevant to right colectomy for cancer: a postmortem study. Surg Endosc 32:3806-3812

4. Nesgaard JM, Stimec BV, Bakka AO, Edwin B, Ignjatovic D (2015) Navigating the mesentery: a comparative pre- and peroperative visualization of the vascular anatomy. Colorectal Dis 17(9):810-818

5. Willard CD1, Kjaestad E1, Stimec BV2, Edwin B3,4, Ignjatovic D5,6; RCC Study Group. Preoperative anatomical road mapping reduces variability of operating time, estimated blood loss, and lymph node yield in right colectomy with extended D3 mesenterectomy for cancer. Int J Colorectal Dis. 2018 Nov 1. doi: 10.1007/s00384-018-3177-5. [Epub ahead of print].

Yazışma Adresi/Address for Correspondence: Dejan Ignjatovic, MD, Institute of Clinical Medicine, University of Oslo, Oslo, Norway E-Posta/E-Mail: dexexer01@hotmail.com || Tel: -

Received/Geliş Tarihi: 02.01.2019 || Accepted/Kabul Tarihi: 08.01.2019

Bu Eser Creative Commons Atıf-Gayriticari 4.0 Uluslararası Lisansı İle Lisanslanmıştır. This work is licensed under a Creative Commons

Attribution-NonCommercial 4.0 International License (CC BY-NC 4.0). 